\title{
Can Better Political Governance Give Australia an Improved Political Class?
}

\author{
Andrew Murray ${ }^{1}$
}

\section{The governance of political parties: the issue}

Australians are demanding much more of their governments. The push for higher standards and better performance is strong. Expectations have been created. The consequent economic, social and environmental reform contemplated in Australia is very large. Plans have been devised that embrace nearly every sector in Australia, yet the political sector has been left largely untouched, as if only the political class at the apex do not need to be more able, of a higher calibre, more productive, more competitive, professionally more suited for the future.

The personal calibre, quality and character of political and public-service leaders matter greatly in delivering better performance. Can better political governance give Australia an improved political class? ${ }^{2}$

This question has even more relevance in the context of markedly smaller membership of political parties than was once the case. That shrunken membership will inevitably have reduced the numbers, quality, and variety of potential candidates for public office.

Poor governance has significant negative effects. Governance through law, regulation and process makes power subject to performance and accountability and leads to better outcomes and conduct; which is why so much effort was put into better governance in the bureaucratic, ${ }^{3}$ union and corporate sectors, with great improvements resulting. In contrast, not much effort has been put into reforming governance in the political sector, although it must be said that at least the reporting of parliamentarians' interests and entitlements has significantly improved in recent years.

\footnotetext{
${ }^{1}$ Senator for Western Australia 1996-2008. This article draws from a section of a lecture given by the author, Essential Linkages - Situating Political Governance Transparency and Accountability in the Broader Reform Agenda, 17 February 2009. This public lecture is available on-line via the ANZSOG Centre for Governance and Public Policy; and has also been reproduced in Critical Reflections on Australian Public Policy selected essays edited by John Wanna, ANU E Press, Canberra, 2009.

2 Recent work by Andrew Murray on political governance includes two public submissions: a response to the Australian Government's December 2008 Electoral Reform Green Paper 'Donations Funding and Expenditure'; and to the Joint Standing Committee on Electoral Matter's inquiry into the conduct of the 2007 federal election (April 2008).

${ }^{3}$ For instance see the definition in page 13 of ANAO and PM\&C 2006 Implementation of Program and Policy Initiatives: Making Implementation Matter, Better Practice Guide Commonwealth of Australia, Canberra.
} 
It is not as if the Commonwealth parliament has not been asked via debate, reports, recommendations and amendments to introduce better regulation along the lines discussed in this article - it has, but the resistance remains strong. As the independent referee for this article rightly remarked, the article 'does not provide a solution to the problem that the proposed new statutory provisions would [need to] be enacted by the current crop of politicians who are the beneficiaries of the existing system ... [but] this hurdle is not insurmountable and does not affect the principle expounded in the article.'

Political parties must be accountable because of the public funding and resources they enjoy and because they materially affect the lives of all Australians. They decide the policies that determine our future, the programs our taxes fund, the Ministers that government agencies respond to and the representatives in parliaments they are accountable to.

\section{The present framework}

Conflicts of interest and the self-interest of politicians have meant minimal statutory regulation of political parties. It is limited and relatively perfunctory, in marked contrast to the much better and stronger regulation for corporations or unions.

The successful functioning and integrity of any organisation rests on solid and honest constitutional foundations. The laws for corporations and unions provide models for organisational regulation. But political parties do not operate on the same foundational constructs.

We have law and governance in the public interest for corporations and unions because it makes a real difference to their integrity and functioning. The laws for the regulation of companies and industrial relations, the Corporations Act and the Fair Work Act, currently number 2400 and 650 pages, respectively. In contrast to lengthy and detailed rules for the governance of corporations and unions in those Acts, there are almost no rules regulating the governance of political parties in the 440-page Commonwealth Electoral Act. ${ }^{4}$

At present there are two governance areas in politics that are, to a degree, regulated by statute - the registration of political parties, and funding and disclosure. The statutory registration of political parties is well managed by the Australian Electoral Commission (AEC), as a necessary part of election mechanics, but the regulation of funding and disclosure is weak.

\footnotetext{
4 As entities, political parties sit within the Third Sector - see Senate Economics Standing Committee report Disclosure regimes for charities and not-for-profit organisations, Canberra, December 2008; One Regulator, One System, One Law: The Case for Introducing a New Regulatory System for the Not for Profit Sector, Senator Andrew Murray, Canberra, July 2006, available from the Parliamentary Library Canberra; and the public submission by Andrew Murray, February 2009 in response to the Australian Government's December 2008 Electoral Reform Green Paper Donations Funding and Expenditure.
} 
Although they are private organisations in their legal form, political parties by their role, function, importance and access to public funding are of great public concern. The courts are catching up to that understanding. ${ }^{5}$ Nevertheless, the common law has been of little assistance in providing necessary safeguards. To date the Courts have been largely reluctant to apply common law principles (such as on membership or pre-selections) to political party constitutions, although they have determined that disputes within political parties are justiciable.

Political governance includes how a political party operates, how it is managed, its corporate and other structures, the provisions of its constitution, how it resolves disputes and conflicts of interest, its ethical culture and its level of transparency and accountability.

Increased regulation of political parties is not inconsistent with protecting the essential freedoms of expression and from unjustified state interference, influence or control.

Greater regulation offers political parties protection from internal malpractice and corruption, and the public better protection from its consequences. It will reduce the opportunity for public and private funds being used for improper purposes. The federal electoral committee has previously agreed with many of these points, but nothing has been done. ${ }^{6}$

Improved political governance will, over time, lift the overall calibre of the political class by requiring greater professionalism, better pre-selection recruitment and training, a sustainable career path for professional parliamentarians as well as those that aspire to an executive ministerial career, and by reducing the opportunity for patronage, sinecures and dynastic factionalism. Australia is fortunate in having many very able politicians, but the overall quality and ability of politicians and ministers - local, state, territory, and federal — needs to be lifted.

A trained, professional, experienced, political class that is subject to the rigours of regulation, due process, and organisational integrity will always perform better than one that is not.

Most work environments or the trades are focused on productivity and performance. In contrast, formal training is curiously neglected in politics, and training is best characterised as 'on the job'. The training our elected representatives get before assuming full duties is perfunctory, haphazard and

\footnotetext{
${ }^{5}$ For instance, Baldwin v Everingham (1993) 1 QLDR 10; Thornley \& Heffernan CLS 1995 NSWSC EQ 150 and CLS 1995 NSWSC EQ 206; Sullivan v Della Bosca [1999] NSWSC 136; Clarke v Australian Labor Party (1999) 74 SASR 109 \& Clarke v Australian Labor Party (SA Branch), Hurley \& Ors and Brown [1999] SASC 365 and 415; Tucker v Herron and others (2001), Supreme Court QLD 6735 of 2001. 6 See Chapter 4 Joint Standing Committee on Electoral Matters (JSCEM) report into the 2004 federal election: September 2005.
} 
limited. It is true that some politicians are already trained in politics, policy and government as former advisers or former public servants, but most are not. Many have no experience in managing an office, a budget and staff. Like all workforces, elected representatives would benefit from better training on entering their new profession. ${ }^{7}$

\section{Some Proposals for Reform}

To bring political parties under the type of accountability regime that befits their role in our system of government, at the very least the following reforms are needed.

The Commonwealth Electoral Act should be amended to require standard items be set out in a political party's constitution to gain registration, similar to the requirements under Corporations Law for the constitution of companies.

Party constitutions should be required to specify the conditions and rules of party membership; how office bearers are pre-selected and selected; how pre-selection of candidates is conducted; the processes for the resolution of disputes and conflicts of interest; the processes for changing the constitution; and processes for administration and management.

Party constitutions should also provide for the rights of members in specified classes of membership to take part in the conduct of party affairs, either directly or through freely chosen representatives; to freely express choices about party matters, including the choice of candidates for elections; and to exercise a vote of equal value with the vote of any other members in the same class of membership.

Party constitutions should be open to public scrutiny and updated on the public register at least once every electoral cycle.

The AEC should be empowered to oversee all important ballots within political parties. At the very least, the law should permit them to do so at the request of a registered political party.

The AEC should also be empowered to investigate any allegations of a serious breach of a party constitution, and be able to apply an administrative penalty.

Changes to political governance such as these do not need $\mathrm{COAG}^{8}$ coordination, although its support would be welcome. Such reforms to

\footnotetext{
${ }^{7}$ Intensive residential courses could be devised. As an example, formal courses might include essential legal principles and legislation design; Australian political parliamentary electoral and constitutional law and systems; government and the bureaucracy in all its complexity; foreign affairs, treaties and diplomacy; accountability, laws systems and practices; procurement and tendering; budget finance and revenue, including cost-benefit analysis; managing a parliamentary office and staff; and so on.

8 The Council of Australian Governments (COAG) is the peak intergovernmental forum in Australia, comprising the Prime Minister, State Premiers, Territory Chief Ministers and the President of the Australian Local Government Association.
} 
Commonwealth law would inevitably flow onto the conduct of state political participants, since nearly all registered state participants are also registered federal parties.

Political parties are at least as significant to society as are corporations and trade unions, if not more so. Governance changes such as those outlined above have been tried, tested and found effective in the governance of corporations, unions and other entities. They would undoubtedly improve the performance and governance of politics in Australia. These are necessary reforms, but whether they would be sufficient on their own to produce a markedly more able and higher-calibre political class overall is uncertain. Other reforms, including constitutional changes, will need to be kept in mind. 